\title{
TESTICULAR SEMINOMA: CORRELATION BETWEEN STAGING AND CHEMOTHERAPY RESPONSE, TWO YEARS OVERALL SURVIVAL RATE
}

\section{Ida Bagus Putra Pramana*, Lukman Hakim, Wahjoe Djatisoesanto, Sunaryo Hardjowijoto}

Urology Department, Faculty of Medicine, Airlangga University, dr. Soetomo General Hospital, Surabaya, Indonesia. *Correspondence: putrapramana0607@gmail.com.

\begin{abstract}
Objective: to determine the patient's characteristics, correlation between staging and chemotherapy response, furthermore two years overall survival rate. Methods: a retrospective analytic study was conducted. Data were obtained from medical records in January 2008 to December 2014 and analyzed using SPSS 17.0. All of correlation between staging and chemotherapy response, primary tumor staging $(\mathrm{pT})$ and metastasis $(\mathrm{M})$, regional lymph nodes staging $(\mathrm{N})$ and metastasis $(\mathrm{M})$, serum tumor marker and chemotherapy response were tested by Spearman correlation test. Two years overall survival rate was analyzed by Kaplan-Meier. Data ratio with normal distribution was tested by Paired T-test. Results: the mean age of patients were $31.03 \pm 13.751$ years, with seven patients (15.6\%) had previous history of undescended testis. Based on TNM staging, we found that most patients had already develop into stage pT3 (46.7\%), N3 (57.7\%), and M0 (57.7\%). A significant correlation between staging and chemotherapy response was shown with stage I of testicular seminoma had completely chemotherapy response $(100 \%)$ and two years overall survival rate in stage I was $100 \%$, whereas in metastatic seminoma (stage II and III) was $60 \%$, with Hazard Ratio 0.63 $(\mathrm{p}=0.294$; 95\%CI 0.276-1.476). Conclusion: patients in early stage of testicular seminoma will give a better response to chemotherapy and will have better survival rate compared to those with metastatic seminoma.
\end{abstract}

Keywords: germ cell tumor, testicular seminoma, chemotherapy response, overall survival rate.

\section{TESTICULAR SEMINOMA: KORELASI ANTARA STAGING DAN RESPON KEMOTERAPI, TINGKAT KELANGSUNGAN HIDUP MENYELURUH SELAMA DUA TAHUN}

\author{
Ida Bagus Putra Pramana*, Lukman Hakim, Wahjoe Djatisoesanto, Sunaryo Hardjowijoto \\ Departemen Urologi, Fakultas Kedokteran, Universitas Airlangga, RSUD dr. Soetomo, Surabaya, Indonesia. \\ *Korespondensi: putrapramana0607@gmail.com.
}

\begin{abstract}
ABSTRAK
Tujuan: untuk menentukan karakteristik pasien, korelasi antara staging dan kemoterapi, serta tingkat keberlangsungan hidup selama dua tahun. Metode: studi analitik retrospektif telah dilakukan. Data didapatkan dari rekam medis, dari Januari 2008 sampai Desember 2014, kemudian dianalisis menggunakan SPSS 17,0. Semua korelasi antara staging dan respon terhadap kemoterapi, staging tumor primer (pT) dan metastase (M), staging kelenjar limfe regional (N) dan metastase (M), serum tumor marker dan respons terhadap kemoterapi diuji menggunakan tes korelasi Spearman. Tingkat keberlangsungan hidup selama dua tahun dianalisis menggunakan Kaplan-Meier. Rasio data dengan distribusi normal diuji dengan Paired T-Test. Hasil: didapatkan usia rata-rata pasien adalah 31,03 \pm 13,751 tahun, dengan tujuh pasien $(15,6 \%)$ memiliki riwayat undescended testis terdahulu.
\end{abstract}


Berdasarkan staging TNM, kami menemukan bahwa kebanyakan pasien terdiagnosis dengan stadium pT3 $(46,7 \%)$, N3 (57,7\%), dan M0 (57,7\%). Korelasi signifikan antara staging dengan respon terhadap kemoterapi ditunjukkan pada stadium I testicular seminoma yang memiliki respon kemoterapi baik (100\%) dan 2 tahun overall survival pada pasien dengan stadium I testicular seminoma adalah 100\%, dimana seminoma metastatik (stadium II dan III) sebanyak 60\%, dengan Rasio Hazard 0,63 ( $\mathrm{p}=0,294 ;$ 95\%CI 0,276-1,476). Simpulan: pasien dengan stadium awal testicular seminoma akan memberikan respon yang lebih baik terhadap kemoterapi dan mempunyai angka keberlangsungan hidup yang lebih baik dibandingkan pada metastasis seminoma.

Kata kunci: tumor sel germinal, testicular seminoma, respon kemoterapi, tingkat keberlangsungan hidup.

\section{INTRODUCTION}

Testicular cancer accounts for $1 \%$ of malignancies in men, and $5 \%$ of all urogenital tumors. ${ }^{1}$ Ninety-four percent of testicular tumors are Germ Cell Tumors (GCT). ${ }^{2}$ Prevalence rate of testicular tumor tend to increase, $55 \%$ in 1973 became $73 \%$ in 2001. About $10 \%$ until $30 \%$ of the cases will come with far metastasis. The data from Surveillance Epidemiology and End Result (SIER) Program (1973-1998) shows that the risk of having seminoma among Caucasian men in United States of America is increasing. ${ }^{3}$ In USA about 8400 people had testicular cancer and 380 people died because of it. GCT can be categorized as seminoma and nonseminoma (NSGCT) based on its pathology and treatment. The incidence of testicular seminoma is increasing compared to that of non-seminoma GCT. ${ }^{4}$ GCT incidence is also increasing around the world. In USA, its prevalence rate among patient with age 15 until 49 years old increased from 2.9 per 100,000 in 1975 became 5.1 per 100,000 in 2004. ${ }^{3}$ Based on a study about testicular cancer at $\mathrm{dr}$. Soetomo General Hospital in 2008 until 2013, there were 37 testicular seminoma cases (80\%), 4 yolk sac tumor cases $(9 \%)$, 1 embryonal tumor case (2\%), 1 teratoma case (2\%), and 3 mixed germ cell tumor cases $(3 \%) .^{5}$

The aim of this study was to determine the characteristics of the patients, correlation between testicular seminoma staging and the response to chemotherapy, as well as two years overall survival rate of patients with testicular seminoma that were managed in our department.

\section{METHODS}

This was a cohort retrospective study. The data of the subject age, tumor stage and location, tumor marker serum level, and type/response/side effect of chemotherapy were obtained from medical records in dr. Soetomo General Hospital Surabaya from January 2008 to December 2014, and analyzed using SPSS 17.0.

Patients diagnosed with testicular seminoma based on the histopathology of the specimen taken from the surgery and get chemotherapy BEP (Bleomycin, Etoposide, and Cisplatin) as many as 1 to 4 cycles, with 30 units of intravenous bleomycin on days 2, 9, and 16; 100 $\mathrm{mg} / \mathrm{m}^{2}$ intravenous etoposide on days $1-5$; and $20 \mathrm{mg} / \mathrm{m}^{2}$ intravenous cisplatin on days 1-5 with the interval 21 days. The chemotherapy response was evaluated based on the Response Evaluation Criteria In Solid Tumor (RECIST) criteria. $^{6}$ The 
subject was categorized to have a complete response if the mass reduced completely, partial response if there was at least 30\% of reduction in the size of lesion, progressive response if there was at least a $20 \%$ increase in the sized of the lesion; and stable or no response if there was no or insufficient reduction of the lesion size. The tumor staging was categorized based on the standardized TNM staging classification.

Data were analyzed by descriptive statistic. Correlation between staging and response to chemotherapy, correlation primary tumor staging (pT) and metastasis (M), correlation regional lymph nodes staging $(\mathrm{N})$ and metastasis $(\mathrm{M})$, correlation serum tumor marker level before operation and response to chemotherapy was tested by Spearman correlation test. Two years overall survival rate was analyzed by Kaplan-Meier and hazard ratio was analyzed by cox-regression, we divided staging group into 2 category, stage I and metastatic seminoma (stage II and III). Laboratory results pre and post chemotherapy is a data ratio with normal distribution and tested by Paired T-test. Statistically significant if $\mathrm{p}<0.05$.

\section{RESULTS}

There were 45 patients with testicular seminoma with mean age of $31.45 \pm 13.67$ years old for patient with stage I and 30.90 \pm 13.97 years old for patient with metastatic seminoma. Location of the tumor was more frequent in right testicle, which occurred in 23 patients $(51.1 \%)$. A total of 7 patients $(15.6 \%)$ were found to have a history of undescended testis. Based on the TNM staging, patients with stage pT3 were as many as 21 patients (46.7\%), pT4 12 patients $(26.7 \%)$, pT2 8 patients $(17.7 \%)$, and pT1 4 patients (8.9
$\%)$. In regional lymph nodes staging $(\mathrm{N})$ $\mathrm{N} 3$ were as many as 26 patients $(57.7 \%)$, N0 12 patients (26.7\%), N2 4 patients (8.9\%), and N1 3 patients (6.7\%). Metastasis staging (M) M0 was found in 26 patients $(57.7 \%), \mathrm{M} 1 \mathrm{~b}$ in 12 patients (26.7\%), and M1a in 7 patients (15.6\%). Based on serum tumor markers (S) parameter, most of the patients were S2 (22 patients, or $48.9 \%$ ), followed by S1 (9 patients, 20.0\%), S0 (9 patients, 20.0\%), and S3 of 5 patients (11.1\%) (Table 1).

Table 1. Patient's characteristics.

\begin{tabular}{|c|c|c|c|c|}
\hline \multirow[b]{2}{*}{ Characteristic } & & \multicolumn{2}{|r|}{$\mathrm{n}$} & \multirow[b]{2}{*}{$\%$} \\
\hline & & $\begin{array}{l}\text { Stage } \\
\text { I }\end{array}$ & $\begin{array}{l}\text { Metastatic } \\
\text { Seminoma }\end{array}$ & \\
\hline Tumor & Right Testis Left & 3 & 20 & 51.1 \\
\hline \multirow[t]{2}{*}{ Location } & Testis & 7 & 11 & 40.0 \\
\hline & Intra-abdominal & 1 & 3 & 8.9 \\
\hline \multirow[t]{2}{*}{ Risk Factor } & UDT & 1 & 6 & 15.6 \\
\hline & Not Known & 10 & 28 & 84.4 \\
\hline Staging & $\mathrm{pT} 1$ & 1 & 3 & 8.9 \\
\hline primary & pT 2 & 3 & 5 & 17.7 \\
\hline \multirow[t]{2}{*}{ tumor $(\mathrm{pT})$} & pT 3 & 4 & 17 & 46.7 \\
\hline & pT 4 & 3 & 9 & 26.7 \\
\hline Staging & No & 11 & 1 & 26.7 \\
\hline regional & N1 & 0 & 3 & 6.7 \\
\hline lymph & $\mathrm{N} 2$ & 0 & 4 & 8.9 \\
\hline nodes $(\mathrm{N})$ & N3 & 0 & 26 & 57.7 \\
\hline Staging & 0 & 11 & 15 & 57.7 \\
\hline Metastasis & $1 \mathrm{a}$ & 0 & 7 & 15.6 \\
\hline$(\mathrm{M})$ & $1 b$ & 0 & 12 & 26.7 \\
\hline Serum & SO & 4 & 5 & 20.0 \\
\hline Tumor & $\mathrm{S} 1$ & 2 & 7 & 20.0 \\
\hline \multirow[t]{2}{*}{ Marker (S) } & $\mathrm{S} 2$ & 5 & 17 & 48.9 \\
\hline & $\mathrm{S} 3$ & 0 & 5 & 11,1 \\
\hline
\end{tabular}

UDT: Undescended Testis.

There were 11 patients $(24.2 \%)$ categorized in the TNM stage I, 5 patients $(11.1 \%)$ with stage II, and 29 patients $(64.5 \%)$ with stage III. The most widely used adjuvant therapy was BEP chemotherapy in 31 patients $(68.8 \%)$, BEP and Radiotherapy in 8 patients (17.8\%), and patient received radiotherapy was 1 patient (2.2\%) (Table 2). From this study result, there are 15 patients $(33.4 \%)$ with complete response to chemotherapy, 19 
patients $(42.2 \%)$ with partial response to chemotherapy and 5 patients $(11.1 \%)$ with no response to chemotherapy (Table 2).

Table 2. Tumor's staging and chemotherapy response.

\begin{tabular}{cccc}
\hline Characteristics & & $\mathrm{n}$ & $\%$ \\
\hline Stage & Stage I & 11 & 24.1 \\
& Stage II & 5 & 11.1 \\
& Stage III & 29 & 64.4 \\
\hline Adjuvant & BEP & 31 & 68.9 \\
therapy & BEP + Radiotherapy & 8 & 17.8 \\
& Carboplatin & 1 & 2.2 \\
& Lost & 4 & 8.9 \\
& Radiotherapy & 1 & 2.2 \\
\hline Response to & Complete Response & 15 & 33.4 \\
Chemotherapy & Partial Response & 19 & 42.2 \\
& No Response & 5 & 11.1 \\
& Lost & 6 & 13.3 \\
\hline
\end{tabular}

BEP: Bleomycin, Etoposide, and Cisplatin.

The number of patients with increasing concentration of $\mathrm{LDH}$ is 29 patients (64.4\%), and 16 patients (35.6\%) have normal concentration of LDH. The average number of the increasing concentration is $745.21 \pm 357.4 \mathrm{U} / \mathrm{l}$. The concentration of AFP is increasing in 12 patients $(26.7 \%)$ and normal in 33 patients (73.3\%). The average increasing number of AFP concentration is $452.8 \mathrm{mIU} / \mathrm{mL} \pm 277.7$. The $\beta$-hCG concentration is increasing in 14 patients $(31.1 \%)$ and normal in 31 patients $(68.9 \%)$. The average increasing number of $\beta$-hCG concentration is $339.6 \pm$ $268.2 \mathrm{ng} / \mathrm{mL}$ (Table 3).

Table 3. Serum tumor marker levels.

\begin{tabular}{ccccc}
\hline $\begin{array}{c}\text { Serum } \\
\text { Tumor } \\
\text { Marker }\end{array}$ & Category & $\mathrm{n}$ & $\%$ & Mean \pm SD \\
\hline LDH & Normal & 16 & 35.6 & $745.2 \pm 357.4$ \\
& Increasing & 29 & 64.4 & \\
\hline AFP & Normal & 33 & 73.3 & 4 \\
& Increasing & 12 & 26.7 & \\
\hline$\beta$-hCG & Normal & 31 & 68.9 & \multirow{2}{*}{$339.6 \pm 267.7$} \\
& Increasing & 14 & 31.1 & \\
\hline
\end{tabular}

LDH: Lactic Dehydrogenase; AFP: AlphaFetoprotein; $\beta$-hCG: Beta-human chorionic gonadotropin; SD: Standard Deviation.
A total of 32 patients $(80 \%)$ complained of nausea and vomiting during chemotherapy, 36 patients (90\%) complained of alopecia, 1 patient $(2.5 \%)$ was reported to be suffering from severe side effects of chemotherapy, which were neurotoxicity and ototoxicity. Most frequent hematologic side effects of chemotherapy were leukopenia and neutropenia, each occurred in 20 patients (50\%). By using Paired T Test comparing pre and post chemotherapy laboratory results, there was a significant reduced leucocytes, neutrophils, and thrombocytes level after patients got chemotherapy $(\mathrm{p}=0.001)$, while pre and post chemotherapy HB level are not significantly different $(\mathrm{p}=0.184)$ (Table 4 and Table 5).

Table 4. Side effect of chemotherapy.

\begin{tabular}{lll}
\hline Side Effect & $\mathrm{n}$ & $\%$ \\
\hline Nausea and Vomiting & 32 & 80 \\
Alopecia & 36 & 90 \\
Neurotoxic, Ototoxic & 1 & 2.5 \\
No Symptoms & 3 & 7.5 \\
\hline
\end{tabular}

Table 5. Hematological side effect of chemotherapy.

\begin{tabular}{lllll}
\hline Side Effect & $\mathrm{n}$ & $\%$ & Mean $\pm \mathrm{SD}$ & $\mathrm{p}$ \\
\hline Leucopenia & 20 & 50.0 & $3005 \pm 0.916$ & 0.001 \\
Neutropenia & 20 & 50.0 & $1.12 \pm 0.24$ & 0.001 \\
Thrombocytopenia & 17 & 42.5 & $96294 \pm 19889$ & 0.001 \\
Anemia & 2 & 5.0 & $9.2 \pm 0.4$ & 0.184 \\
\hline \multicolumn{2}{l}{ SD: Standard Deviation. } & & &
\end{tabular}

SD: Standard Deviation.

Based on Spearman correlation test, there is no significant correlation between stage $\mathrm{pT}$ and $\mathrm{M}(\mathrm{r}=0.155, \mathrm{p}=0.310)$, while the correlation between stage $\mathrm{N}$ and $\mathrm{M}$ is significant $(\mathrm{r}=0.419, \mathrm{p}=0.004)$. This means the increasing staging $\mathrm{N}$ will be followed by an increasing staging M (Table 6 and Table 7).

The value of rho ( $r$ ) and $p$ for the correlation between chemotherapy 
response and tumor marker serum are $\mathrm{r}=0.296$ and $\mathrm{p}=0.067$. It means there is a weak correlation between chemotherapy response and tumor marker serum and it's not statistically significant (Table 8).

Table 6. Correlation between staging $\mathrm{pT}$ and $\mathrm{M}$.

\begin{tabular}{ccccccccc}
\hline & & \multicolumn{5}{c}{ Staging pT } & r & p \\
\cline { 3 - 6 } & & pT1 & pT2 & pT3 & pT4 & & \\
\hline $\begin{array}{c}\text { Staging } \\
\text { Metastasis } \\
(\text { M })\end{array}$ & M0 & 3 & 6 & 11 & 6 & & \\
& M1a & 0 & 0 & 5 & 2 & 0.155 & 0.31 \\
& M1b & 1 & 2 & 5 & 4 & &
\end{tabular}

Table 7. Correlation between staging $\mathrm{N}$ and $\mathrm{M}$.

\begin{tabular}{ccccccccc}
\hline & \multicolumn{5}{c}{$\begin{array}{c}\text { Staging regional } \\
\text { lymph nodes (N) }\end{array}$} & & $\mathrm{r}$ & $\mathrm{p}$ \\
\cline { 3 - 6 } & & $\mathrm{N} 0$ & $\mathrm{~N} 1$ & $\mathrm{~N} 2$ & $\mathrm{~N} 3$ & & \\
\hline Staging & M0 & 11 & 3 & 1 & 11 & & \\
Metastasis & M1a & 0 & 0 & 2 & 5 & 0.419 & 0.004 \\
$(\mathrm{M})$ & M1b & 1 & 0 & 1 & 10 & & \\
\hline
\end{tabular}

Table 8. Correlation between tumor marker serum and chemotherapy response.

\begin{tabular}{ccccccc}
\hline & \multicolumn{3}{c}{ Response chemotherapy } & & \\
\cline { 2 - 4 } & $\begin{array}{c}\text { Complete } \\
\text { response }\end{array}$ & $\begin{array}{c}\text { Partial } \\
\text { response }\end{array}$ & $\begin{array}{c}\text { No } \\
\text { Response }\end{array}$ & r & p \\
\hline S0 & 5 & 4 & 0 & & \\
S1 & 3 & 3 & 1 & 0.296 & 0.067 \\
S2 & 7 & 10 & 3 & & \\
S3 & 0 & 2 & 1 & & \\
\hline
\end{tabular}

In patients with stage I testicular seminoma, 10 patients had complete responses $(100 \%)$, while in patients with stage II there were 1 patients with complete response $(25 \%)$ and 2 patients with partial responses $(75 \%)$, while in patients with stage III there were 4 patients with complete response (15.4\%), 17 patients with partial response $(65.4 \%)$, and 5 patients with no response $(19.2 \%)$ with $\mathrm{r}=0.685$ and $\mathrm{p}=0.001$. This shows a significant correlation between the staging of testicular seminoma and the response to chemotherapy (Table 9).

Based on this study, percentages of having 2 years overall survival rate in stage I patients is $100 \%$, while in metastatic seminoma patients (stage II and III) is $60 \%$ (Figure 1). 10 patients with metastatic seminoma died during 2 years follow up, the hazard rate value is 0.63 , it means that patients with metastatic seminoma tend to have fatal possibility 0.63 times comparing to those with stage I testicular seminoma. But it is not statistically significant $(\mathrm{HR}=0.63,95 \% \mathrm{CI}$ 0.26-1.476, $\mathrm{p}=0.294$ ).

Table 9. Correlation between staging and chemotherapy response.

\begin{tabular}{lccccc}
\multicolumn{6}{c}{ chemotherapy response. } \\
& \multicolumn{2}{c}{ Response Chemotherapy } & r & p \\
\cline { 2 - 6 } & Complete & Partial & No & & \\
& Response & Response & Response & & \\
\hline Stage I & 9 & 0 & 0 & & \\
Stage II & 1 & 2 & 0 & 0.679 & 0.001 \\
Stage III & 4 & 17 & 5 & & \\
\hline
\end{tabular}

Survival Functions

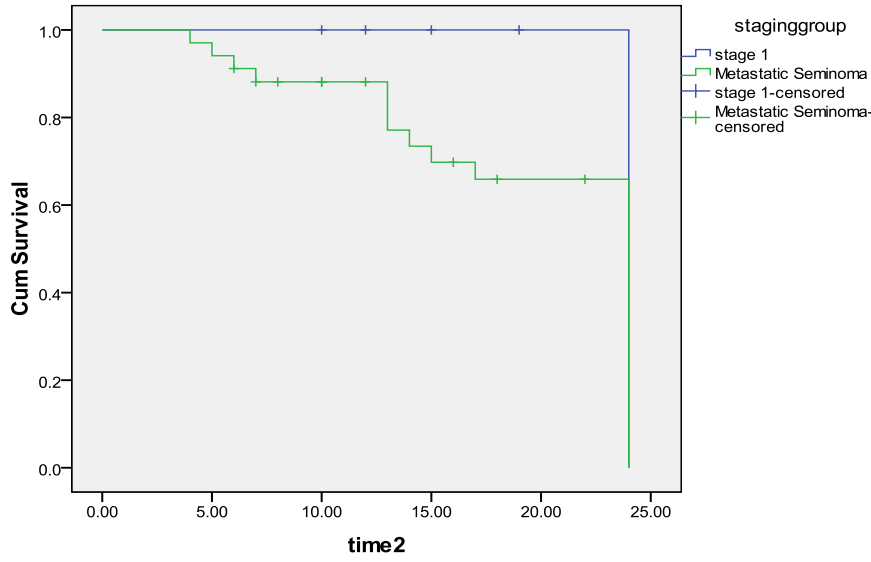

Figure 1. Kaplan-Meier graphic comparing the two years overall survival rate between stage I testicular seminoma and metastatic seminoma.

\section{DISSCUSION}

Testicular cancer is the most common cancer found in men age 15-35 years old. ${ }^{3}$ Testicular seminoma often occurred in the $4^{\text {th }}$ decade of life, while non-seminoma often happens in the $3^{\text {rd }}$ decade of life. ${ }^{5}$ The incidence is rare in men age under 15 years old or over 60 years old. Its prevalence among children only 0.5-2.0 
per 100,000 population. $^{6}$ The age distribution in children also different than in adult. ${ }^{7}$ Based on study result, there are 45 testicular seminoma patients with average age in stage $I$ is $31.45 \pm 13.67$ years old and in metastatic seminoma is $30.90 \pm 13.97$ years old.

Testicular cancer often occurs in the right side rather than left side, and it also happens in patient with cryptorchidismus. ${ }^{8}$ The most important factor that considered having correlation with testicular cancer is cryptorchidism history on the testis. About $7-10 \%$ testicular cancer patients have cryptorchidism history, seminoma is the common testicular cancer that happen among this kind of patients. Cryptorchidism raises the chance of having testicular cancer 4 until 6 times higher. The risk is higher in testis located intra-abdominal (1 in 20 cases), and significantly lower in testis located in inguinal ( 1 in 80 cases). ${ }^{9}$ Based on study result, tumor located in right testis is more common, 23 patients $(51.1 \%)$, than left testis, 18 patients $(40.0 \%)$, and intraabdominal testis, and 4 patients (8.9\%). History of undescended testis presences in 7 patients $(15.6 \%)$.

Although fetal AFP serum level is high, after 1 year old, it becomes very low. ${ }^{9}$ AFP will not increase in pure seminoma or choriocarcinoma. ${ }^{3}$ Increasing level of $\beta$ hCG did not occurred in pure embryonal cell carcinoma, this cancer cell does not contain syncytiotrophoblast, increasing level of AFP in pure embryonal cell carcinoma is rare and if it is occurred, it usually accompanied by yolk sac tumor. ${ }^{4}$ There are many combinations of mixed tumor, usually it consists of embryonal cell carcinoma, seminoma, yolk sac, teratoma or synctiotrophoblast. ${ }^{10}$ Based on the type of base cells, AFP level usually increases in yolk sac tumor, and $\beta$-hCG level increases if the element of syncytiotrophoblas exist. ${ }^{4}$ Tumor marker serum is an important value for diagnosis (before orchiectomy) also for prognosis (after orchiectomy). AFP and $\beta$-hCG are increasing in $50-70 \%$ and $40-60 \%$ patients with NSGCT. The increasing of one or two tumor markers is happened in almost $90 \%$ NSGCT. The $\beta$-hCG increases in almost $30 \%$ of seminoma patients during the progression of the disease. $\mathrm{LDH}$ is a non-specific tumor marker, its concentration increasing equal to tumor volume. The $\beta$-hCG usually increases in $80 \%$ testicular cancer patient with older age. Placenta Alkali Phosphatase (PLAP) is a tumor marker that can be checked in patient with pure seminoma, but it is not recommended for smoker. ${ }^{4}$ Based on study result, 12 patients $(26.7 \%)$ are with increasing concentration of AFP, while 33 patients $(73.3 \%)$ are with normal concentration of AFP. The average increasing number of AFP concentration is $452.8 \mathrm{mIU} / \mathrm{mL} \pm 277.7$. The $\beta$-hCG concentration is increasing in 14 patients $(31.1 \%)$ and normal in 31 patients $(68.9 \%)$. The average increasing number of $\beta$-hCG concentration is $339.6 \mathrm{ng} / \mathrm{mL} \pm$ 268.2 .

Based on the previous study, seminoma was said to be highly sensitive to platinum-containing chemotherapy. ${ }^{11}$ However, the present data show contrary result. Majority of the subjects showed partial response (42.2\%). Regardless of that, the recurrence of seminoma was high. These masses resolve slowly over months, and although residual masses are commonly present one month after completion of chemotherapy. ${ }^{12}$

In stage IIA/B seminoma, radiotherapy could provide excellent results, as the 
majority of patient will be cured with this treatment alone. Chemotherapy is the treatment of choice for stage IIC seminoma. ${ }^{13}$

The cause of neutropenia, leucopenia, and thrombocytopenia are side effect of etoposide and cisplatin which is suppression of bone marrow so leucocytes and thrombocytes production is decreasing. ${ }^{14}$ Alopecia is the most common side effect of bleomycin and etoposide, this is happened because the chemotherapy drugs blocking cellular absorption in hair follicle so hair growth is disturbed. ${ }^{15}$

In the analysis of tumor size or $\mathrm{T}$ category, this study showed the tumor size was correlated neither with clinical substage nor relapse rate. There was a poorer 3-years survival for anaplastic seminomas as compared to that of classical seminoma, the difference was not significant. ${ }^{16}$ A risk adapted chemotherapy policy for advanced seminoma yielded an excellent outcome with a 3 years overall survival rate was $96 \%$ and 5-years overall survival rate was $92 \% .^{17}$

In this study, no correlation between $\mathrm{pT}$ staging with $\mathrm{M}$ and serum tumor marker after the operation with chemotherapy response. Significant correlation between $\mathrm{N}$ and $\mathrm{M}$ staging, which means the higher $\mathrm{N}$ staging it will be followed by an increase in $M$ staging and vice versa. In this study also found a positive correlation between staging and response to chemotherapy, it is means patient in advanced stage cancer will give a poor response to chemotherapy. In this study, 2 years overall survival rate for patients with stage I seminoma testicular better when compared with metastatic seminoma, but this was not statistically significant.

\section{CONCLUSION}

Testicular seminoma mostly appears in younger males. Testicular seminoma is chemosensitive. Patients in early stage will give a better response to chemotherapy compared to those with advanced stage. After chemotherapy, evaluation should be done to the patient's complaints and complete blood count to detect side effects. Patients with stage I testicular seminoma have a better two years overall survival rate compared to those with metastatic seminoma, but the difference was not significant.

\section{REFERENCES}

1. Sánchez-Ortiz RF, Vaughn DJ. Renal, Testicular, and Penile Cancer. In: Hanno PM, Malkowicz SB, Wein AJ, editors. Penn Clinical Manual of Urology. Philadelphia: Saunders; 2007. p.571-616.

2. McGlynn KA, Quraishi SM, Graubard BI, et al. Persistent Organochlorine Pestisides and Risk of Testicular Germ Cell Tumors. J Natl Cancer Inst. 2008;100:663-71.

3. Albers P, Albercth P, Algaba F, et al. Guideline of Testicular Cancer. Netherlands: European Urology Association; 2015. p50-86.

4. Kramer A, Siroky MB. Neoplasma of the Genitourinary Tract. In: Siroky $\mathrm{MB}$, Oates RD, Babayan RK, editors. Handbook of Urology: Diagnosis and Therapy. $3^{\text {rd }}$ Edition. Philadelphia: Lippincott Williams and Wilkins; 2004. p.249-99.

5. Mukti AI, Hardjowijoto S. Profile of Testicular Cancer in Soetomo Hospital Surabaya. Surabaya: Universitas Airlangga; 2015.

6. Eisenhauer EA, Therasse P, Bogaerts J, et al. New Response Evaluation 
Criteria in Solid Tumours: Revised RECIST Guideline (version 1.1). Eur J Cancer. 2009;45:228-47.

7. Ross JH, Kay R. Prepubertal testis tumors. Rev Urol. 2004;6:11-8.

8. Motzer RJ, Jonasch E, Agarwal N, et al. Testicular Cancer, Version 2.2015. $J$ Natl Compr Canc Netw. 2015;13:772-99.

9. Stephenson AJ, Gilligan TD. Neoplasm of the Testis. In: Wein AJ, Kavoussi LR, Novick AC, et al, editors. Campbell-Walsh Urology. $10^{\text {th }}$ Edition. Philadelphia: Saunders; 2012. p.837-70.

10. Zhou M, Netto G, Epstein J, editors Uropathology: A Volume in the High Yield Pathology. Philadelphia: Saunders; 2012. p.383-432.

11. Acar C, Gurocak S, Sozen S. Current Treatment of Testicular Sex CordStromal Tumors: Critical Review. Urology. 2009;73:1165-71.

12. Peckhman MJ, Horwich A, Hendry WF. Advanced Seminoma: Treatment with Cis-platinum-Based Combination Chemotherapy or Carboplatin (JM8). Br J Cancer. 1985;52:7-13.

13. Li YX, Coucke PA, Qian TN, et al. Clinical Characteristics, Prognosis, and Treatment of Pelvic Cryptorchid Seminoma. Int J Radiat Oncol Biol Phys. 1997;38:351-7.

14. Chung PW, Gospodarowicz MK, Panzarella T, et al. Stage II Testicular Seminoma: Patterns of Recurrence and Outcome of Treatment. Eur Urol. 2004;45:754-60.

15. Christian JA, Huddart RA, Norman A, et al. Intensive Induction Chemotherapy with CBOP/BEP in Patients with Poor Prognosis Germ Cell Tumors. $J$ Clin Oncol. 2003;21:871-7.
16. Evensen JF, Fosså SD, Kjellevold K, et al. Testicular Seminoma: Histological Findings and Their Prognostic Significance for Stage II Disease. $J$ Surg Oncol. 1987;36:166-9.

17. Fizazi K, Delva R, Caty A, et al. A Risk-Adapted Study of Cisplatin and Etoposide, with or without Ifosfamide, in Patients with Metastatic Seminoma: Results of The GETUG S99 Multicenter Prospective Study. Eur Urol. 2014;65:381-6. 